\title{
Effect of low-dose beclomethasone dipropionate on asthma control and airway inflammation
}

\author{
J.V. Fahy, H.A. Boushey
}

Effect of low-dose beclomethasone dipropionate on asthma control and airway inflammation. J.V. Fahy, H.A. Boushey. OERS Journals Ltd 1998.

ABSTRACT: The effects of usual or low doses of inhaled corticosteroids on airway mucosal inflammation have not yet been examined.

We therefore, compared the effects of inhaled beclomethasone dipropionate (BDP) $336 \mu \mathrm{g} \cdot \mathrm{day}^{-1}$ on asthma control outcomes and markers of airway inflammation.

Twenty-four adult subjects with mild and moderate asthma were randomized to receive either BDP or placebo for four weeks; then subjects entered a single blind four week placebo run-in period.

We found that the BDP group had significantly greater improvements in forced expiratory volume in one second (FEV1), morning peak flow, and rescue salbutamol use than the placebo-treated group. The improvement in FEV1 largely reversed one week after treatment was stopped. The decrease in the median percentage of eosinophils in induced sputum in the BDP group from $3.8 \%$ to $3.4 \%$ was not significant, but because eosinophils increased from $8.4 \%$ to $12.7 \%$ in the placebo group, there was a significant difference between treatment groups $(p=0.03)$. There was no significant difference between groups during treatment in the levels of eosinophil cationic protein (ECP), tryptase mucin-like glycoprotein, or fibrinogen in induced sputum. The change in FEV1 in the BDP group did not correlate significantly with the change in eosinophil percentage or ECP levels.

We concluded that four weeks of treatment with inhaled beclomethasone dipropionate $336 \mu \mathrm{g} \cdot \mathrm{day}^{-1}$ was associated with significant improvements in peak flow, forced expiratory volume in one second, and rescue salbutamol use in asthmatic subjects but was not associated with large reductions in markers of eosinophilic inflammation, bronchovascular permeability, or mucus hypersecretion.

Eur Respir J 1998; 11: 1240-1247.
Dept of Medicine and the Cardiovascular Research Institute, University of California, San Francisco, California, USA.

Correspondence: J.V. Fahy

Box 0130

University of California

San Francisco

505 Parnassus Avenue

San Francisco

CA 94143

USA

Fax: 14154765712

Keywords: Asthma

beclomethasone dipropionate

eosinophils

eosinophil cationic protein

induced sputum

tryptase

Received: June 301997

Accepted after revision February 151998

Supported by a Research Grant from Glaxo Wellcome Inc.
Studies of fluid obtained by bronchial lavage, of mucosal tissue obtained by bronchial biopsy, and of sputum obtained by sputum induction, have established that asth$\mathrm{ma}$ is associated with airway inflammation [1-9]. Other studies have demonstrated that high doses of inhaled corticosteroid for periods of up to 16 weeks significantly reduce markers of inflammation in airway mucosal biopsies in subjects with mild asthma [10-12]. High doses of inhaled corticosteroids are not necessary to improve asthma control in patients with mild persistent asthma however [13-15], and current guidelines suggest that usual doses, not high doses, of inhaled corticosteroid should be prescribed for patients with mild persistent asthma [16]. To our knowledge, the effects of usual or low doses of inhaled corticosteroids on airway mucosal inflammation in asthma have not yet been examined.

In this study, our aim was to determine whether the improvements in indices of asthma control produced by a relatively low dose of an inhaled corticosteroid are associated with a reduction in markers of airway inflammation. Thus, we conducted a randomized, parallel-group, placebo-controlled study of the effects of beclomethasone dipropionate (BDP; $336 \mu \mathrm{g} \cdot \mathrm{day}^{-1}$ ) on measures of asthma control and markers of inflammation in induced sputum. The study design was a 4-week double-blind treatment period followed by a 4 -week single-blind placebo run-out period. The run-out period was incorporated to allow determination of the "off-effect" of inhaled BDP, i.e. the duration of persistence of any BDP-induced improvements in asthma control and airway inflammation when treatment was stopped.

\section{Materials and methods}

\section{Subjects}

Twenty four asthmatic subjects were studied. Inclusion criteria were a history of symptoms of asthma and bronchial hyperreactivity to methacholine provocative concentration causing a $20 \%$ fall in forced expiratory volume in one second $\left(\mathrm{PC}_{20}\right.$ ð8 $\left.\mathrm{mg} \cdot \mathrm{mL}^{-1}\right)$. Exclusion criteria were inhaled or oral steroid use or history of an upper respiratory infection in the previous 6 weeks, and tobacco use 
within the past year or $>10$ pack-yrs total smoking history. Subjects were recruited from advertisements placed in local newspapers or from the database of subjects who had previously participated in asthma studies at our centre. The recruitment strategy for the study did not include asking potential subjects to discontinue inhaled corticosteroid medications so that they could participate in the study. Forced expiratory volume in one second (FEV1) and sputum eosinophil percentage were not used as entry criteria. Subject characteristics on visit 1 are shown in table 1. Although randomized according to a table of random numbers, three subjects in the placebo group had an FEV1 $<80 \%$ predicted on visit 1 , whereas six subjects in the BDP group had an FEV1 pred at $<80 \%$. The mean FEV1 at baseline in the two groups was not significantly different however $(\mathrm{p}=0.8)$. All subjects showed a skin test positivity to at least one aeroallergen, and all subjects signed consent forms approved by the Committee on Human Research at the University of California, San Francisco.

\section{Protocol}

The study involved nine visits to the laboratory over 10 weeks. The study design was a randomized, parallel group, placebo-controlled study with a 2-week run-in, a 4week double-blind placebo-controlled treatment period, and a 4-week single-blind placebo run-out period. There were three visits during the run-in. On the first visit (day -14), consent was obtained, and spirometry, allergen skin testing and methacholine challenge were performed. Salbutamol inhalers were provided for symptomatic control of asthma symptoms, and subjects were instructed to complete a diary card that recorded peak flow (MiniWright Peak Flow Meter, Clement Clarke, Columbus, OH), asthma symptoms salbutamol use and nocturnal asthma awakenings. Subjects were asked to measure their peak flow in the morning, immediately upon awakening before inhaler use, and again in the evening, if possible, $4 \mathrm{~h}$ after the last inhaler use. The asthma symptoms component of the diary captured symptoms of shortness of breath, chest tightness, wheezing, cough and sputum rated daily by the subject on a scale from 0 (none) to 10 (severe). The maximum possible daily score was $50(5 \times 10)$ and the maximum possible weekly score was $350(7 \times 50)$. Diary cards were reviewed and collected at all study visits. On the second visit (day -7 , beginning of the second week), spirometry and sputum

Table 1. - Clinical characteristics of the study subjects on visit $1 *$

\begin{tabular}{llc}
\hline & $\begin{array}{c}\text { Placebo } \\
(\mathrm{n}=12)\end{array}$ & $\begin{array}{c}\text { Beclomethasone } \\
(\mathrm{n}=12)\end{array}$ \\
\hline Age yrs & $32 \pm 9$ & $34 \pm 9$ \\
Females \% & 50 & 33 \\
FEV1 \% pred & $89 \pm 21$ & $79 \pm 25$ \\
FEF25-75\% & $58 \pm 27$ & $51 \pm 35$ \\
PC20 $\mathrm{mg} \cdot \mathrm{mL}^{-1}$ & $0.09(0.02-1.11)$ & $0.16(0.02-1.27)$ \\
\hline
\end{tabular}

*: values represent the mean and standard deviation except for the $\mathrm{PC}_{20}$ methacholine, which is presented as the geometric mean and the range. FEV1: forced expiratory volume in one

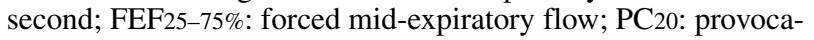
tive concentration of methacholine causing a 20\% fall in FEV1. induction were performed, and these were repeated on the third visit (beginning of the third week) before subjects were randomized to the study drug.

There were two visits during the double blind-treatment period. The first of these visits (day 7, study visit 4) was 1 week after the study drug course was started, and the second (day 28, study visit 5) was 3 weeks later. Spirometry and sputum induction were performed on both visits.

There were four visits during the single blind-placebo run-out period. The first of these (day 30, study visit 6) was 2 days after visit 5 and was for methacholine challenge. The second was 5 days later (day 35, study visit 7), and the third was 3 weeks later (day 56, study visit 8 ); spirometry and sputum induction were performed during both visits. The last visit was 2 days after visit 8 (day 58 , study visit 9) and was for methacholine challenge.

\section{Study medication}

The study medication was administered by a metered dose inhaler. The dose of the study medication was four puffs twice daily. The beclomethasone inhaler contained $42 \mu \mathrm{g} \cdot$ puff- $^{-1}$ (the standard dose in Beclovent ${ }^{\mathrm{TM}}$ and Vanceril $^{\mathrm{TM}}$ inhalers in USA), so that the total dose of beclomethasone per day was $336 \mu$ g. Subjects were asked to use an Ellipse ${ }^{\mathrm{TM}}$ spacer device (Allen and Hanburys, Division of Glaxo Inc., Research Triangle Park, NC, USA) which has a volume of $200 \mathrm{~mL}$. Compliance was encouraged by reminders during the study visits to take the study drug; between visits, telephone contact was made on days 14 and 21 (between visits 4 and 5) and again on days 42 and 49 (between visits 7 and 8) to encourage compliance.

\section{Spirometry}

Bronchodilators were withheld for $8 \mathrm{~h}$ prior to testing. Spirometry was performed using a rolling seal Ohio 840 spirometer (Ohio Medical Products, Houston, TX, USA) according to American Thoracic Society (ATS) criteria [17]. Flow volume loops were generated by acquiring and digitizing the electrical volume signal versus time produced by a rolling seal spirometer and then scaling these digitized computer counts to litres by application of a calibration factor. Flow was derived from the change in volume over the change in time (in real time), and flow versus volume was displayed on a graphic cathode-ray screen and printed on hardcopy. All spirometric values including peak expiratory flow (PEF) were calculated from the raw data (i.e. volume versus time), and the values reported are the best of three separate manoeuvres.

\section{Methacholine challenge}

Methacholine challenge was performed using a method modified from Снаг et al. [18]. Methacholine was diluted in calcium and magnesium-free phosphate-buffered saline (PBS) and delivered from a hand-held nebulizer (DeVilbiss No. 646, Somerset, PA, USA) connected to a dosemetering device (driven by compressed oxygen at 138 
$\mathrm{kPa}$ ) and equipped with a critical orifice, $7 \mathrm{~mm}$ in diameter, at the inflow end to allow a maximum inspiratory flow of $500 \mathrm{~mL} \cdot \mathrm{min}^{-1}$. Inspiration by the subject triggered a solenoid valve in the dosimeter to open for $2.1 \mathrm{~s}$ and deliver an average of $15.1 \mu \mathrm{L}$ of methacholine from a 2 $\mathrm{mL}$ reservoir. Each subject took five inhalations of aerosol breathing from functional residual capacity to total lung capacity each time. Single FEV1 manoeuvres were recorded 1 and 3 min after the subject inhaled PBS diluent, and the best of these manoeuvres was used as the baseline FEV1. The initial concentration of methacholine administered was $0.03 \mathrm{mg} \cdot \mathrm{mL}^{-1}$, and a dose-response curve was constructed by administering serial doubling concentrations of methacholine at $5 \mathrm{~min}$ intervals until the worst FEV1 manoeuvre recorded 1 or 3 min after methacholine inhalation was $ð 80 \%$ of the baseline FEV1. The PC20 was calculated by linear interpolation between the last two points on the dose-response curve.

\section{Allergen skin testing}

Skin prick testing was performed using standardized disposable allergy prick test needles (Morrow Brown, Topeka, KA, USA). Eleven common inhalant allergens were used, six of which (house dust, alternaria, cat hair, dog hair, Dermatophagoides pteronyssinus, D. farinae and diluent control) were obtained from Miles Laboratories, (Spokane, WA, USA) and five of which (house dust, mixed grass pollen, hormodendrum, mixed trees, mixed weeds and histamine control) were obtained from Berkeley Biological (Berkeley, CA, USA). If the skin wheel diameter caused by the allergen was $3 \mathrm{~mm}$ larger than that of the diluent control, then the skin test was considered positive.

\section{Sputum induction}

Sputum induction was performed as previously described [9]. Briefly, all subjects were pretreated with $360 \mu \mathrm{g}$ salbutamol administered by a metered dose inhaler, and then were seated in a Nuaire aerosol containment chamber (model no. NU-810-224, Plymouth, MN, USA). They inhaled nebulized sterile $3 \%$ saline for $20 \mathrm{~min}$ from a DeVilbiss Ultraneb 99 ultrasonic nebulizer, the reservoir of which was filled with $100 \mathrm{~mL}$ of $3 \%$ saline (this nebulizer generates particles of a mean mass median diameter of $4.5 \mu \mathrm{M}$, and the maximal output measured as the volume of saline delivered to the mouthpiece is $\left.1.2 \mathrm{~mL} \cdot \mathrm{min}^{-1}\right)$. Subjects were encouraged to cough throughout the procedure and regularly interrupted inhalation of hypertonic saline in order to expectorate all secretions, including both sputum and saliva, into a clean plastic container.

\section{Sputum processing}

Sputum was processed according to previously published methods [9]. In brief, induced sputum was overlaid with an equal volume of $0.01 \%$ dithiothreitol and the mixture was placed in a shaking water bath for $15 \mathrm{~min}$ at $37^{\circ} \mathrm{C}$ to facilitate complete homogenization. Sputum cell differ- entials were calculated on cytospin preparations of cells stained with DiffQuik (DiffQuik Scientific Products, McGaw Park, IL, USA). The cell differentials were presented as the percentage of nonsquamous cells in the induced sputum. Eosinophil cationic protein (ECP) and tryptase concentrations in induced sputum supernatant samples were determined using sensitive radioimmunoassays (RIAs; Pharmacia Diagnostics Inc., Fairfield, NJ, USA). Mucinlike glycoprotein levels were determined by enzyme-linked immunosorbent assay (ELISA) as previously described [19].

\section{Statistics}

Baseline values were calculated as the averages of the different outcomes recorded during the 2-week run-in period. Within-group changes in outcome variables in the BDP and placebo groups were each compared using the paired t-test or the Wilcoxon signed rank test, as appropriate. Between-group changes in outcome variables were compared using the unpaired t-test or the Mann-Whitney U-test, as appropriate. Spearman's rank order tests were used to determine correlations between the data. A probability value of $<0.05$, with a two-tailed test, was considered significant.

\section{Results}

All 12 subjects randomized to treatment with BDP completed all study visits. Of the 12 subjects in the placebo group, two developed an asthma exacerbation during the run-out period that necessitated their withdrawal from the study, and one other was withdrawn because of failure to comply with the study protocol. Data on withdrawn subjects were included in the data set up to the time of withdrawal.

\section{Pulmonary function, salbutamol use and asthma symp- toms}

We found that the mean FEV1, forced mid-expiratory flow (FEF25-75\%), and morning peak flow rates increased significantly more during the double-blind treatment period in the BDP group than in the placebo group (table 2, fig. 1). The PC20 for methacholine was 0.7-fold higher than baseline at the end of the double-blind treatment period in the BDP group (i.e. the bronchial reactivity to methacholine decreased, $\mathrm{p}=0.38$ ), but this change was not significantly greater than the 0.4 -fold increase seen in the placebo group ( $\mathrm{p}=0.7$ between groups) (table 3 ).

The frequency of rescue salbutamol inhalations fell significantly more from baseline over the course of treatment with BDP than with placebo (table 2, fig. 1), but asthma symptoms that were minor at baseline did not change significantly during the double-blind treatment period in either treatment group. BDP-associated improvements in peak flow, spirometric values and salbutamol use largely reversed 1 week after the double-blind treatment was stopped (table 2, fig. 1). 
Table 2. - Pulmonary function, rescue salbutamol use during treatment with study medication

\begin{tabular}{|c|c|c|c|c|c|c|}
\hline \multirow[t]{2}{*}{ Outcome } & \multirow[b]{2}{*}{ Baseline } & \multicolumn{2}{|c|}{ Treatment } & \multicolumn{2}{|l|}{ Run-out } & \multirow[b]{2}{*}{ Day 56} \\
\hline & & Day 7 & Day 28 & Day 30 & Day 35 & \\
\hline Placebo & $(\mathrm{n}=12)$ & $(\mathrm{n}=12)$ & $(\mathrm{n}=12)$ & $(\mathrm{n}=11)$ & $(n=11)$ & $(\mathrm{n}=9)$ \\
\hline FEV1 L & $2.9 \pm 0.9$ & $3.0 \pm 1.1$ & $2.9 \pm 1.1$ & $3.1 \pm 1.3$ & $3.1 \pm 0.7$ & $3.3 \pm 1.0$ \\
\hline FEF $25-75 \%$ & $2.1 \pm 1.1$ & $2.3 \pm 1.3$ & $2.0 \pm 1.2$ & $2.3 \pm 1.3$ & $2.2 \pm 1.0$ & $2.7 \pm 1.4$ \\
\hline Morning PEF L·min ${ }^{-1}$ & $386 \pm 121$ & $380 \pm 130$ & $371 \pm 145$ & $\mathrm{NA}$ & $419 \pm 160$ & $420 \pm 150$ \\
\hline Salbutamol puffs-week-1 & $38 \pm 30$ & $45 \pm 32$ & $45 \pm 38$ & $\mathrm{NA}$ & $36 \pm 35$ & $26 \pm 17$ \\
\hline Symptoms $\cdot$ week $^{-1 *}$ & $33 \pm 13$ & $32 \pm 12$ & $31 \pm 13$ & $\mathrm{NA}$ & $31 \pm 16$ & $29 \pm 15$ \\
\hline Beclomethasone & $(n=12)$ & $(n=12)$ & $(\mathrm{n}=12)$ & $(n=12)$ & $(\mathrm{n}=12)$ & $(n=12)$ \\
\hline FEV1 L & $2.8 \pm 0.9$ & $3.2 \pm 1.0 *$ & $3.3 \pm 0.9^{*,+}$ & $3.2 \pm 0.9 *$ & $2.9 \pm 1.0$ & $2.9 \pm 1.0$ \\
\hline FEF $25-75 \%$ & $2.0 \pm 1.3$ & $2.4 \pm 1.2^{*}$ & $2.6 \pm 1.3^{*,+}$ & $2.4 \pm 1.2 *$ & $2.1 \pm 1.3$ & $2.0 \pm 1.3$ \\
\hline Morning PEF L.min ${ }^{-1}$ & $371 \pm 145$ & $410 \pm 150^{+}$ & $404 \pm 144^{*++}$ & NA & $392 \pm 149$ & $393 \pm 148$ \\
\hline Salbutamol puffs-week-1 & $37 \pm 26$ & $29 \pm 24^{+}$ & $23 \pm 24^{+}$ & NA & $28 \pm 25$ & $30 \pm 25$ \\
\hline Symptoms $\cdot$ week $^{-1} *$ & $34 \pm 10$ & $31 \pm 13$ & $29 \pm 16$ & $\mathrm{NA}$ & $28 \pm 18$ & $28 \pm 13$ \\
\hline
\end{tabular}

Values presented as mean \pm SD. FEV1: forced expiratory volume in one second; FEF25-75\%: forced mid-expiratory flow; PEF: peak expiratory flow averaged for preceeding 7 days; NA: not applicable; salbutamol puffs·week-1: total number of puffs of salbutamol per week; symptoms week $^{-1}$ : asthma symptoms presented as a composite of the weekly score (the maximum total weekly score was $350(7 \times 50))$. * $\mathrm{p}<0.05$ compared to baseline within the group, but $\mathrm{p}=$ nonsignificant to the change in the placebo group. ${ }^{+}: \mathrm{p}<0.05$ compared to baseline within and between groups.
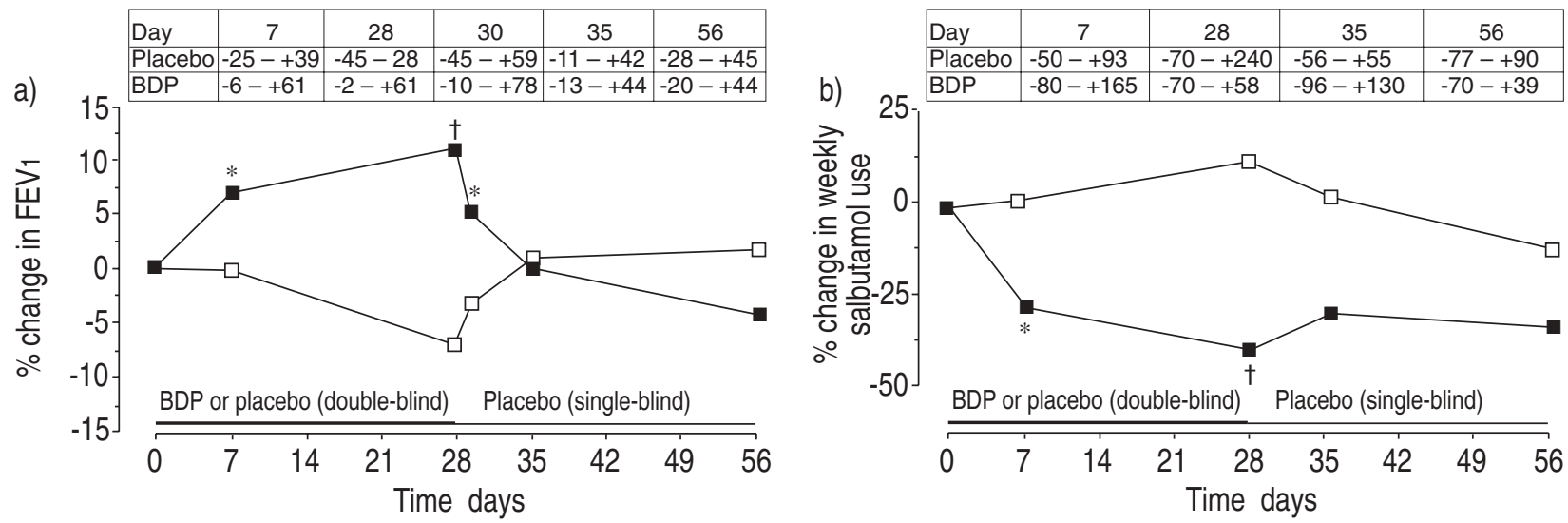

Fig. 1. - Median changes in: a) forced expiratory volume in one second (FEV1); and b) in weekly salbutamol use from pretreatment baseline to the end of the double-blind and single-blind treatment periods for subjects randomized to inhaled beclomethasone dipropionate (BDP; $\mathbf{\square})$ or inhaled placebo ( $\square$ ). Inset tables indicate the range of the percentage change in the values for FEV1 (a) and salbutamol use (b). See table 2 for the number of subjects at each time point. The baseline values for FEV1 represent the average of the three measurements of FEV1 made during visits 1 , 2 and 3 . The baseline weekly salbutamol use represents the average of the salbutamol puffs-week ${ }^{-1}$ for the two baseline weeks of the study. *: significantly different from baseline $(\mathrm{p}<0.05)$, but not significantly different from corresponding change in placebo group. ${ }^{\dagger}$ : significantly different from baseline and from the corresponding change in placebo group $(\mathrm{p}<0.05)$.

Table 3. - Methacholine reactivity during and after treatment with study medication*

\begin{tabular}{lccc}
\hline & Baseline & Treatment & Run-out \\
& Day -14 & Day 30 & Day 58 \\
\hline Placebo & $(\mathrm{n}=12)$ & $(\mathrm{n}=10)$ & $(\mathrm{n}=9)$ \\
PC20 mg $\cdot \mathrm{mL}^{-1}$ & $0.09(0.02-1.11)$ & $0.14(0.03-1.06)$ & $0.08(0.02-0.23)$ \\
Beclomethasone & $(\mathrm{n}=12)$ & $(\mathrm{n}=12)$ & $(\mathrm{n}=12)$ \\
PC20 mg $\cdot \mathrm{mL}^{-1}$ & $0.16(0.02-1.27)$ & $0.27(0.03-6.28)$ & $0.27(0.08-3.58)$ \\
\hline *. & values represent geometric $\mathrm{mean}$ and range. $\mathrm{PC} 20:$ provocative concentration causing a $20 \%$ fall in
\end{tabular}

. values represent geometric mean and range. PC20: provocative concentration causing a $20 \%$ fall in forced expiratory volume in one second.

\section{Markers of inflammation in induced sputum}

The percentage of eosinophils in induced sputum was not significantly different at baseline in the two groups $(p=0.4)$. The percentage of eosinophils in induced sputum decreased slightly from baseline to the end of treatment in the BDP treated group, but this decrease was not statistically significant (table 4 , fig. 2 ). The percentage of eosinophils in induced sputum increased in the placebo group, and the change in sputum eosinophil percentage differed significantly between groups (table 4, fig. 2). The sputum eosinophil percentages in the BDP group increased back to baseline within 1 week after treatment was discontinued. The levels of tryptase in induced sputum decreased significantly from baseline to the end of treatment in the BDP group (table 5), but this change did not differ from the placebo-treated group $(p=0.16)$. The levels of $E C P$, fibrinogen, and mucin-like glycoprotein in induced sputum did not change significantly within, or between, groups during treatment (table 5). 
Table 4. - Median values (range) for total and differential cell counts in induced sputum at baseline, during and after treatment with study medication

\begin{tabular}{|c|c|c|c|c|c|c|}
\hline \multirow[t]{2}{*}{ Outcome } & \multicolumn{2}{|c|}{ Baseline } & \multicolumn{2}{|c|}{ Treatment } & \multicolumn{2}{|c|}{ Run-out } \\
\hline & Day -7 & Day 0 & Day 7 & Day 28 & Day 35 & Day 56 \\
\hline Placebo & $(n=12)$ & $(\mathrm{n}=12)$ & $(\mathrm{n}=12)$ & $(\mathrm{n}=12)$ & $(\mathrm{n}=10)$ & $(n=9)$ \\
\hline Cell count $10^{5} \cdot \mathrm{mL}^{-1}$ & $\begin{array}{l}10.9 \\
(4.0-74.5)\end{array}$ & $\begin{array}{l}13.2 \\
(3.0-44.8)\end{array}$ & $\begin{array}{l}16.7 \\
(2.9-40.4)\end{array}$ & $\begin{array}{l}17.5 \\
(2.9-42.4)\end{array}$ & $\begin{array}{l}30.9 \\
(5.3-54.4)\end{array}$ & $\begin{array}{l}25.2 \\
(3.2-71.3)\end{array}$ \\
\hline$\%$ Squamous & $\begin{array}{l}38.1 \\
(13.4-89.2)\end{array}$ & $\begin{array}{l}33.5 \\
(8.5-89.3)\end{array}$ & $\begin{array}{l}42.0 \\
(9.3-79.5)\end{array}$ & $\begin{array}{l}46.7 \\
(10.7-96.0)\end{array}$ & $\begin{array}{l}36.0 \\
(14.4-90.0)\end{array}$ & $\begin{array}{l}38.7 \\
(6.7-92.7)\end{array}$ \\
\hline$\%$ Epithelial $^{+}$ & $\begin{array}{l}2.4 \\
(0.0-21.5)\end{array}$ & $\begin{array}{l}2.0 \\
(0.0-8.2)\end{array}$ & $\begin{array}{l}1.5 \\
(0.2-3.7)\end{array}$ & $\begin{array}{l}1.8 \\
(0.0-17.4)\end{array}$ & $\begin{array}{l}1.1 \\
(0.0-17.3)\end{array}$ & $\begin{array}{l}1.4 \\
(0.0-5.6)\end{array}$ \\
\hline$\%$ Neutrophil ${ }^{+}$ & $\begin{array}{l}38.5 \\
(9.9-76.3)\end{array}$ & $\begin{array}{l}46.0 \\
(3.1-9.4)\end{array}$ & $\begin{array}{l}36.9 \\
(3.7-84.9)\end{array}$ & $\begin{array}{l}43.1 \\
(6.5-72.4)\end{array}$ & $\begin{array}{l}33.1 \\
(21.2-74.7)\end{array}$ & $\begin{array}{l}41.0 \\
(0.0-81.7)\end{array}$ \\
\hline$\%$ Macrophage $^{+}$ & $\begin{array}{l}43.8 \\
(13.9-74.2)\end{array}$ & $\begin{array}{l}39.9 \\
(8.4-84.8)\end{array}$ & $\begin{array}{l}51.0 \\
(11.6-96)\end{array}$ & $\begin{array}{l}35.6 \\
(19.1-79.4)\end{array}$ & $\begin{array}{l}37.1 \\
(16.6-66.4)\end{array}$ & $\begin{array}{l}39.9 \\
(13.6-100)\end{array}$ \\
\hline$\%$ Lymphocyte $^{+}$ & $\begin{array}{l}0.6 \\
(0.0-4.7)\end{array}$ & $\begin{array}{l}0.9 \\
(0.2-7.1)\end{array}$ & $\begin{array}{l}0.8 \\
(0.0-2.4)\end{array}$ & $\begin{array}{l}1.0 \\
(0.0-2.3)\end{array}$ & $\begin{array}{l}0.6 \\
(0.0-3.0)\end{array}$ & $\begin{array}{l}0.2 \\
(0.0-1.1)\end{array}$ \\
\hline$\%$ Eosinophil $^{+}$ & $\begin{array}{l}8.4 \\
(0.0-35.0)\end{array}$ & $\begin{array}{l}5.8 \\
(0.2-34.6)\end{array}$ & $\begin{array}{l}5.5 \\
(0.0-46.3)\end{array}$ & $\begin{array}{l}12.7 \\
(1.7-57.7)\end{array}$ & $\begin{array}{l}10.1 \\
(1.6-56.8)\end{array}$ & $\begin{array}{l}10.5 \\
(0.0-24.2)\end{array}$ \\
\hline Beclomethasone & $(\mathrm{n}=12)$ & $(\mathrm{n}=12)$ & $(\mathrm{n}=12)$ & $(\mathrm{n}=12)$ & $(\mathrm{n}=12)$ & $(n=12)$ \\
\hline Cell count $10^{5} \cdot \mathrm{mL}^{-1}$ & $\begin{array}{l}18.0 \\
(6.0-100.0)\end{array}$ & $\begin{array}{l}18.8 \\
(6.5-57.6)\end{array}$ & $\begin{array}{l}23.1 \\
(11.6-38.8)\end{array}$ & $\begin{array}{l}17.3 \\
(6.6-101.0)\end{array}$ & $\begin{array}{l}25.1 \\
(6.2-60.5)\end{array}$ & $\begin{array}{l}21.2 \\
(7.9-69.0)\end{array}$ \\
\hline$\%$ Squamous & $\begin{array}{l}31.3 \\
(9.8-45.0)\end{array}$ & $\begin{array}{l}32.2 \\
(2.5-60.8)\end{array}$ & $\begin{array}{l}29.1 \\
(3.9-56.2)\end{array}$ & $\begin{array}{l}26.4 \\
(9.2-46.2)\end{array}$ & $\begin{array}{l}30.9 \\
(0.4-58.1)\end{array}$ & $\begin{array}{l}37.0 \\
(15.0-63.4)\end{array}$ \\
\hline$\%$ Epithelial $^{+}$ & $\begin{array}{l}1.8 \\
(0.2-8.1)\end{array}$ & $\begin{array}{l}1.3 \\
(0.0-19.7)\end{array}$ & $\begin{array}{l}1.2 \\
(0.0-5.4)\end{array}$ & $\begin{array}{l}1.1 \\
(0.0-8.7)\end{array}$ & $\begin{array}{l}1.05 \\
(0.2-9.3)\end{array}$ & $\begin{array}{l}2.0 \\
(0.2-7.6)\end{array}$ \\
\hline$\%$ Neutrophil $^{+}$ & $\begin{array}{l}58.1 \\
(11.9-76.7)\end{array}$ & $\begin{array}{l}42.8 \\
(18.3-81.7)\end{array}$ & $\begin{array}{l}54.9 \\
(24.1-95.0)\end{array}$ & $\begin{array}{l}43.9 \\
(17.6-89.3)\end{array}$ & $\begin{array}{l}63.6 \\
21.2-87.3)\end{array}$ & $\begin{array}{l}55.4 \\
(27.1-82.2)\end{array}$ \\
\hline$\%$ Macrophage $^{+}$ & $\begin{array}{l}28.0 \\
(14.6-74.3)\end{array}$ & $\begin{array}{l}41.4 \\
(16.3-72.0)\end{array}$ & $\begin{array}{l}48.8 \\
(9.1-72.8)\end{array}$ & $\begin{array}{l}48.8 \\
(9.1-72.8)\end{array}$ & $\begin{array}{l}31.1 \\
(10.4-58.1)\end{array}$ & $\begin{array}{l}36.2 \\
(9.9-60.8)\end{array}$ \\
\hline$\%$ Lymphocyte $^{+}$ & $\begin{array}{l}0.3 \\
(0.0-2.7)\end{array}$ & $\begin{array}{l}0.9 \\
(0.0-3.2)\end{array}$ & $\begin{array}{l}0.7 \\
(0.0-5.0)\end{array}$ & $\begin{array}{l}0.4 \\
(0.0-2.2)\end{array}$ & $\begin{array}{l}0.5 \\
(0.0-3.0)\end{array}$ & $\begin{array}{l}0.8 \\
(0.0-2.7)\end{array}$ \\
\hline$\%$ Eosinophil $^{+}$ & $\begin{array}{l}4.1 \\
(0.0-23.2)\end{array}$ & $\begin{array}{l}3.6 \\
(0.0-47.4)\end{array}$ & $\begin{array}{l}1.5^{*} \\
(0.0-18.0)\end{array}$ & $\begin{array}{l}3.4^{\#} \\
(0.0-33.6)\end{array}$ & $\begin{array}{l}2.9 \\
(0.0-27.9)\end{array}$ & $\begin{array}{l}5.5 \\
(0.0-37.2)\end{array}$ \\
\hline
\end{tabular}

+: percentage of nonsquamous cells; *: $\mathrm{p}<0.05$ compared to baseline within the group, but nonsignificant compared to the change in the placebo group. \#: $\mathrm{p}<0.05$ compared to baseline between groups but not within the group.
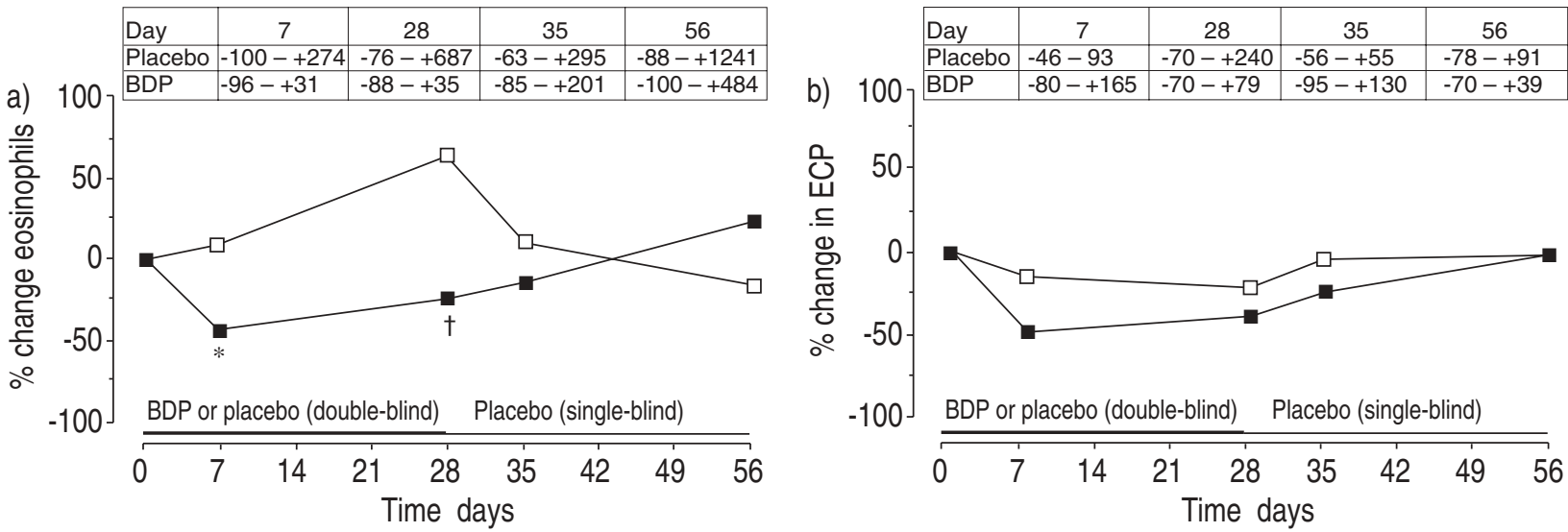

Fig. 2. - Median changes in: a) eosinophils percentage; and b) eosinophil cationic protein (ECP) levels in induced sputum from pretreatment baseline to the end of the double-blind and single-blind treatment periods for subjects randomized to inhaled beclomethasone dipropionate (BDP; $\mathbf{\square}$ ) or inhaled placebo ( $\square$ ). Inset tables indicate the range of the percentage change in the values for eosinophils (a) and ECP (b). See tables 4 and 5 for the number of subjects at each time point. The baseline values for eosinophil percentage and ECP were averaged from the data from two baseline sputum inductions (visit 2 and visit 3$)$. *: significantly different from baseline $(\mathrm{p}<0.05)$, but not significantly different from corresponding change in placebo group. ${ }^{\dagger}$ : significantly different from the corresponding change in placebo group $(\mathrm{p}<0.05)$, but not significantly different from baseline.

\section{Correlations}

The change in FEV1 from baseline to the end of the double-blind treatment period was assessed by examining: 1) the correlation of the change in FEV1 (in L) with the changes in the percentages of eosinophils, levels of ECP, and levels of tryptase in induced sputum; and 2) the corre- lation of the percentage change in FEV 1 with the percentage changes in eosinophils (\%) levels of ECP, and levels of tryptase in induced sputum.

Taking both groups together, using both methods of correlation, there was a significant correlation between treatment-induced change in FEV1 and change in percentage eosinophils $r_{s}=-0.59$ and $r_{s}-0.61, p<0.05(n=24)$ (fig. 3$)$. In 
Table 5. - Median values (range) for markers of inflammation in induced sputum during and after treatment with study medication

\begin{tabular}{|c|c|c|c|c|c|c|}
\hline \multirow[t]{2}{*}{ Outcome } & \multicolumn{2}{|c|}{ Baseline } & \multicolumn{2}{|c|}{ Treatment } & \multicolumn{2}{|c|}{ Run-out } \\
\hline & Day -7 & Day 0 & Day 7 & Day 28 & Day 35 & Day 56 \\
\hline Placebo & $(\mathrm{n}=12)$ & $(n=12)$ & $(n=12)$ & $(n=12)$ & $(\mathrm{n}=10)$ & $(\mathrm{n}=9)$ \\
\hline $\mathrm{ECP} \mathrm{ng} \cdot \mathrm{mL}^{-1}$ & $\begin{array}{l}289 \\
(15-1890)\end{array}$ & $\begin{array}{l}229 \\
(10-3780)\end{array}$ & $\begin{array}{l}260 \\
(9-1520)\end{array}$ & $\begin{array}{l}245 \\
\quad(10-3030)\end{array}$ & $\begin{array}{l}268 \\
(31-4390)\end{array}$ & $\begin{array}{l}267 \\
(16-2730)\end{array}$ \\
\hline Tryptase $\mathrm{U} \cdot \mathrm{L}^{-1}$ & $\begin{array}{l}2.5 \\
(0.0-49.0)\end{array}$ & $\begin{array}{l}2.8 \\
(1.0-26.0)\end{array}$ & $\begin{array}{l}1.5 \\
(0.0-32.0)\end{array}$ & $\begin{array}{l}2.3 \\
(0.0-27.4)\end{array}$ & $\begin{array}{l}3.0 \\
(0.0-9.4)\end{array}$ & $\begin{array}{l}1.7 \\
(0.0-19.0)\end{array}$ \\
\hline Fibrinogen $\mathrm{mg} \cdot \mathrm{mL}^{-1}$ & $\begin{array}{l}1.1 \\
(0.3-8.7)\end{array}$ & $\begin{array}{l}1.3 \\
(0.3-8.4)\end{array}$ & $\begin{array}{l}0.6 \\
(0.2-8.4)\end{array}$ & $\begin{array}{l}1.1 \\
(0.2-4.9)\end{array}$ & $\begin{array}{l}1.0 \\
(0.0-11.6)\end{array}$ & $\begin{array}{l}0.8 \\
(0.0-21.7)\end{array}$ \\
\hline MLG $\mathrm{mg} \cdot \mathrm{mL}^{-1}$ & $\begin{array}{l}4.4 \\
(0.4-9.7)\end{array}$ & $\begin{array}{l}3.6 \\
(0.7-14.9)\end{array}$ & $\begin{array}{l}4.2 \\
(0.7-8.6)\end{array}$ & $\begin{array}{l}4.2 \\
(0.3-11.5)\end{array}$ & $\begin{array}{l}4.3 \\
(0.5-19.5)\end{array}$ & $\begin{array}{l}4.0 \\
(0.1-16.9)\end{array}$ \\
\hline Beclomethasone & $(\mathrm{n}=12)$ & $(n=12)$ & $(\mathrm{n}=12)$ & $(\mathrm{n}=12)$ & $(n=12)$ & $(n=12)$ \\
\hline $\mathrm{ECP} \mathrm{ng} \cdot \mathrm{mL}^{-1}$ & $\begin{array}{l}246.5 \\
\quad(65-1082)\end{array}$ & $\begin{array}{l}302 \\
\quad(90-1240)\end{array}$ & $\begin{array}{l}156 \\
\quad(52-910)\end{array}$ & $\begin{array}{l}175 \\
(47-1932)\end{array}$ & $\begin{array}{l}191 \\
(25-620)\end{array}$ & $\begin{array}{l}235 \\
(48-840)\end{array}$ \\
\hline Tryptase U.L ${ }^{-1}$ & $\begin{array}{l}3.5 \\
(0.0-17.5)\end{array}$ & $\begin{array}{l}4.4 \\
(0.0-8.7)\end{array}$ & $\begin{array}{l}1.6^{*} \\
(0.0-4.1)\end{array}$ & $\begin{array}{l}1.5^{*} \\
(0.0-6.2)\end{array}$ & $\begin{array}{l}1.5 \\
(0.0-11.2)\end{array}$ & $\begin{array}{l}2.1 \\
(1.0-11.4)\end{array}$ \\
\hline Fibrinogen $\mathrm{mg} \cdot \mathrm{mL}^{-1}$ & $\begin{array}{l}2.4 \\
(0.7-8.2)\end{array}$ & $\begin{array}{l}2.6 \\
(0.5-4.9)\end{array}$ & $\begin{array}{l}2.0 \\
(0.7-7.0)\end{array}$ & $\begin{array}{l}1.9 \\
(0.3-3.7)\end{array}$ & $\begin{array}{l}0.9 \\
(0.01-4.3)\end{array}$ & $\begin{array}{l}1.5 \\
(0.2-6.1)\end{array}$ \\
\hline MLG $\mathrm{mg} \cdot \mathrm{mL}^{-1}$ & $\begin{array}{l}3.0 \\
(1.1-11.3)\end{array}$ & $\begin{array}{l}4.0 \\
(1.1-12.8)\end{array}$ & $\begin{array}{l}4.2 \\
(2.8-10.9)\end{array}$ & $\begin{array}{l}4.3 \\
(2.2-20.5)\end{array}$ & $\begin{array}{l}3.9 \\
(1.5-11.1)\end{array}$ & $\begin{array}{l}3.5 \\
(0.8-11.5)\end{array}$ \\
\hline
\end{tabular}

ECP: eosinophil cationic protein; MLG: mucin-like glycoprotein. $*: \mathrm{p}<0.05$ compared to baseline within the group but nonsignificant compared to the change in the placebo group.

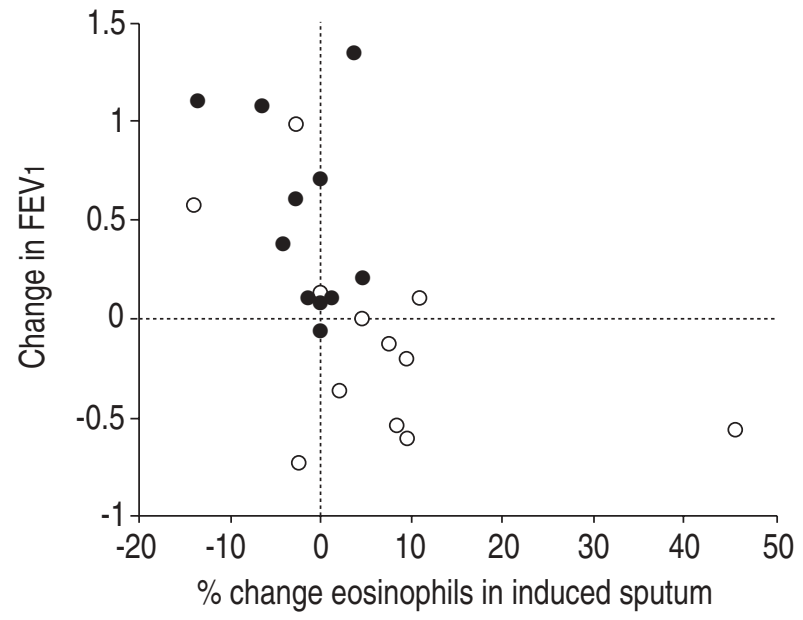

Fig. 3. - Scatter plot of the difference in eosinophil percentage in induced sputum from baseline to end of active treatment versus difference in forced expiratory volume in one second (FEV1) in L from baseline to the end of active treatment in the beclomethasone dipropionate $(\bullet)$ and placebo groups (O). The significant Spearman rank order correlation coefficient for these variables for both groups taken together $\left(\mathrm{r}_{\mathrm{s}}=-0.59, \mathrm{p}<0.05\right)$ was driven more by the inverse correlation in the beclomethasone dipropionate group $\left(r_{s}=-0.15, p=0.6\right)$.

the BDP-treated group, however, using either method, there was no significant correlation between treatmentinduced change in FEV1 and change in percentage eosinophils, indicating that the correlation found for both groups together was driven more by the inverse correlation in the placebo group $\left(r_{\mathrm{s}}=-0.40, \mathrm{p}=0.18\right)$ than by the inverse correlation in the BDP group $\left(\mathrm{r}_{\mathrm{s}}=-0.15, \mathrm{p}=0.6\right)$. Taking both groups together, using method 1 but not method 2 for correlation, there was a significant correlation between the treatment-induced change in FEV 1 and the change in tryptase levels in sputum $(\mathrm{r}=-0.59, \mathrm{p}<0.05(\mathrm{n}=24))$. In the BDP-treated group, however, using either method, there was no significant correlation between a treatment-induced change in FEV1 and a change in tryptase, indicating that the correlation found for both groups together was driven more by the significant inverse correlation in the placebo group $\left(r_{s}=-0.7, p=0.01\right)$ than by the inverse correlation in the BDP group $\left(\mathrm{r}_{\mathrm{s}}=-0.2, \mathrm{p}=0.51\right)$. There was no significant correlation between the change in FEV1 and the change in ECP levels in induced sputum.

\section{Discussion}

In this study we found that inhaled BDP at a dose of $336 \mu \mathrm{g} \cdot$ day $^{-1}$ improved pulmonary function and decreased the frequency of salbutamol use significantly more than inhaled placebo in asthmatic subjects; these BDP-associated improvements were short-lived when treatment was stopped. We also found that inhaled BDP was not associated with large reductions in the percentage of eosinophils or other inflammatory markers in induced sputum, but sputum markers of inflammation did not worsen in the BDP group, whereas they did worsen in the placebo group. The relatively low dose of inhaled BDP used in this study was associated with clinically and statistically significant improvements in morning peak flow, FEV1, FEF25-75\% and rescue salbutamol use. These results are similar to those of other studies that have investigated the effects of relatively low doses of inhaled corticosteroids on pulmonary function outcomes in asthmatic subjects [13-15]. In our study, however, we also investigated the duration of clinical benefit after BDP treatment was stopped. Analysis of this "off effect" adds to that which can be learned from analysing the period when a treatment is being administered, for agents that are thought to be "disease modifying", such as inhaled steroids, they would be expected to have a longer off-effect than simple "symptom relieving" agents, such as inhaled $\beta$-agonists. We found that spirometric indices of airflow obstruction declined to near baseline just 1 week after BDP treatment was discontinued, although treatment-associated improvements in morning peak expiratory flow and salbutamol use lasted longer. 
This short off-effect of inhaled corticosteroid has also been reported by others. VATHENEN et al. [20] studied the offeffects of inhaled budesonide, BEL et al. [21] studied the off-effects of inhaled BDP, and both groups reported that the beneficial effects of these medications on FEV1 and asthma symptoms are short-lived when the treatment is stopped.

Despite the clear improvements that inhaled BDP treatment caused in pulmonary function and rescue salbutamol use, we found that BDP treatment only caused a modest and statistically insignificant decrease in the percentage of eosinophils in induced sputum; furthermore, there was no correlation between the changes in sputum eosinophils and the changes in FEV1 in the BDP group. The average sputum eosinophil percentage increased from baseline during treatment in the placebo group, paralleling a clinical deterioration reflected by a decrease in morning peak flow, an increase in rescue salbutamol use, and two drop-outs because of asthma exacerbations. Consequently, the significant difference in the change in sputum eosinophils between groups at the end of the treatment phase, and the significant correlation between change in sputum eosinophils and change in FEV1 for both groups taken together, were both driven more by the increase in sputum eosinophils and deterioration in FEV1 in the placebo group than by the changes in the BDP group. Neither BDP nor placebo treatment had any significant effect on the levels of ECP, fibrinogen, or mucin-like glycoprotein in induced sputum, although inhaled BDP was associated with a significant within-group reduction in tryptase levels. We do not think that the absence of large changes in markers of inflammation in induced sputum from the BDP-treated group reflects any deficiency in the sensitivity of the technique for sampling airway secretions, for we have found such changes in induced sputum samples in other studies of similar numbers of asthmatic subjects treated with oral prednisone [17] or inhaled fluticasone at low and high doses [22].

The effects of BDP on inflammatory markers in induced sputum described in this study could be interpreted as demonstrating a dissociation between the effects of relatively low doses of inhaled BDP on indicators of asthma control and its effects on indicators of airway inflammation i.e. that asthma control is improved by relatively low dose inhaled BDP treatment but airway inflammation is not. This interpretation is provocative because it challenges conventional wisdom about the mechanism of action of inhaled corticosteroids. This interpretation does not necessarily contradict the studies demonstrating that inhaled corticosteroid treatment significantly reduces airway inflammation in asthmatic subjects [7, 10-12], but the studies that have done so have used doses of inhaled corticosteroid in a range 500-1000 $\mu \mathrm{g} \cdot \mathrm{day}^{-1}$. Trial designs that deliver these doses of inhaled steroids may miss dissociations between the doses of inhaled corticosteroids required to reduce asthma symptoms, improve airway calibre, reduce bronchial reactivity, or prevent exacerbations, and the doses required to decrease airway inflammation. Our data suggest that inhalation of $336 \mu \mathrm{g} \cdot$ day $^{-1}$ BDP suffices to improve airway calibre and reduce salbutamol use in patients with mild asthma but does not suffice to effect large changes in markers of airway eosinophilic inflammation, mucus hypersecretion or bronchovascular permeability. An alternative interpretation of our data is that small reductions in airway inflammation (too small to be detected by our methods and sample size) are sufficient to result in significant improvements in asthma control. In our study, the between group difference for the change in sputum eosinophil percentage from baseline to the end of active treatment was statistically significant, largely because of an increase in sputum eosinophils in the placebo group. This finding might mean that corticosteroid-induced stabilization of eosinophils or of eosinophil numbers in the airway suffices to control asthma.

Presently, our understanding of the relationship between changes in inflammation in the airway and changes in pulmonary function or other outcome indicators of asthma control is very limited because of a paucity of dose-response studies with inhaled or oral corticosteroids, which have included outcome indicators of airway inflammation. Perhaps relevant here though, is our finding in this study that the improvement in bronchial reactivity to methacholine was not significantly greater in the BDPtreated group than in the placebo-treated group (change in PC20 of 0.7 doubling doses versus a change of 0.4 doubling doses, respectively; $p=0.4$ ). This result confirms that all the beneficial effects of inhaled corticosteroid therapy do not necessarily follow the same dose-response pattern. For example, PEDERSEN et al. [15] have previously shown in children with mild-to-moderate asthma that the maximal improvements in symptoms and morning peak flow are achieved with lower doses of inhaled budesonide than those necessary to achieve maximal reduction in bronchial reactivity to exercise. Thus, another interpretation of our data is that the dose-response curve, or even perhaps, the mechanisms of action for beclomethasone's effects on symptoms and peak flow may be different from the doseresponse curve or mechanism of action for its effects on bronchial hyperresponsiveness or on eosinophilic inflammation of the bronchial mucosa. Decisions about the optimum dosing of inhaled corticosteroids will need to await prospective dose comparison studies examining which of these outcomes best predicts optimum long-term asthma control; the outcome indicators of long term asthma control will need to include not only maximal airflow and bronchial reactivity but also asthma exacerbation rates and an outcome indicator of airway remodelling (perhaps changes in airway calibre measured over $1-2 \mathrm{yr}$ periods of time).

The duration of treatment with beclomethasone as well as the daily dose may be an important determinant of the outcome of treatment. For example, the 4-week duration of beclomethasone treatment studied here was sufficient for improvements in FEV1 and in rescue salbutamol use, but it is possible that a longer treatment with beclomethasone at the same dose may have resulted in a greater improvement in bronchial hyperresponsiveness or on the markers of airway inflammation measured. For markers of inflammation, at least, this possibility is not supported by our data because we found no trend for greater effects of beclomethasone on these markers after 4 weeks of treatment compared to 1 week of treatment. Our data on the effects of beclomethasone on methacholine reactivity need to be interpreted more cautiously. This outcome was only measured once during active treatment (4 weeks after treatment began) and it was measured 2 days after active treatment was stopped, and therefore, the maximal effects of this dose of beclomethasone on methacholine reactivity 
may have been underestimated. VAthenen et al. [20] have reported that the effects of budesonide on methacholine reactivity may diminish within $36 \mathrm{~h}$ of treatment cessation.

In summary, we conclude that beclomethasone dipropionate treatment $\left(336 \mu \mathrm{g} \cdot \mathrm{day}^{-1}\right)$ of subjects with mild asthma produces clinically significant improvements in peak flow and in rescue salbutamol use without producing large reductions in markers of airway inflammation in induced sputum samples. This may indicate a dissociation between the doses of inhaled corticosteroids necessary to improve clinical indices of asthma control from those needed to inhibit bronchial mucosal inflammation.

Acknowledgements: The authors would like to thank S. Harding, A. van As, for assistance in the design of the protocol and to J. Liu, T. Ward, H. Cunha and H. Wong, for assistance with the conduct of the clinical trial.

\section{References}

1. De Monchy JGR, Henk HF, Venge P, et al. Bronchoalveolar eosinophilia during allergen-induced late asthmatic reactions. Am Rev Respir Dis 1985; 131: 373-376.

2. Djukanovic R, Roche WR, Wilson JW, et al. State of the art: mucosal inflammation in asthma. Am Rev Respir Dis 1990; 142: 434-457.

3. Wardlaw AJ, Dunnette S, Gleich GJ, Collins JV, Kay AB. Eosinophils and mast cells in bronchoalveolar lavage in subjects with mild asthma. Am Rev Respir Dis 1988; 137: 62-69.

4. Kirby JG, Hargreave FE, Gleich GJ, O'Byrne PM. Bronchoalveolar cell profiles of asthmatic and non-asthmatic subjects. Am Rev Respir Dis 1987; 136: 379-383.

5. Foresi A, Bertorelli G, Pesci A, Chetta A, Oliveri D. Inflammatory markers in bronchoalveolar lavage and in bronchial biopsy in asthma during remission. Chest 1990; 98: 528-535.

6. Mattoli S, Mattoso VL, Soloperto M, Allegra L, Fasoli A. Cellular and biochemical characteristics of bronchoalveolar lavage fluid in symptomatic nonallergic asthma. $J$ Allergy Clin Immunol 1991; 87: 794-802.

7. Adelroth E, Rosenhall L, Johansson SA, Linden M, Venge P. Inflammatory cells and eosinophilic activity in asthmatics investigated by bronchoalveolar lavage. Am Rev Respir Dis 1990; 142: 91-99.

8. Pin I, Gibson PG, Kolendowicz R, et al. Use of induced sputum cell counts to investigate airway inflammation in asthma. Thorax 1992; 47: 25-29.

9. Fahy JV, Liu J, Wong H, Boushey HA. Cellular and biochemical analysis of induced sputum from asthmatic and from healthy subjects. Am Rev Respir Dis 1993; 147: $1126-1131$.

10. Laitinen L, Laitinen A, Haahtela T. A comparative study of the effects of an inhaled corticosteroid, budesonide, and a $\beta_{2}$-agonist, terbutaline, on airway inflammation in newly diagnosed asthma: a randomized, double-blind, parallel-group controlled trial. J Allergy Clin Immunol 1992; 90: $32-42$.

11. Trigg CJ, Manolitsas ND, Wang J, et al. Placebo-controlled immunopathologic study of four months of inhaled corticosteroids in asthma. Am J Respir Crit Care Med 1994; 150: 17-22.

12. Booth H, Richmond I, Ward C, Gardiner PV, Harkawat R, Walters EH. Effect of high dose inhaled fluticasone propionate on airway inflammation in asthma. Am J Respir Crit Care Med 1995; 152: 45-52.

13. Juniper EF, Kline PA, Vanzieleghem MA, Pamsdale EH, O'Byrne PM, Hargreave FE. Effect of long-term treatment with an inhaled corticosteroid (budesonide) on airway hyperresponsiveness and clinical asthma in nonsteroid-dependent asthmatics. Am Rev Respir Dis 1990; 142: 832836.

14. Chervinsky P, Van As A, Bronsky EA, et al. Fluticasone propionate aerosol for the treatment of adults with mild to moderate asthma. J Allergy Clin Immunol 1994; 94: 676683.

15. Pedersen $\mathrm{S}$, Hansen OR. Budesonide treatment of moderate and severe asthma in children: a dose-response study. J Allergy Clin Immunol 1995; 95: 29-33.

16. Institute NHLaB. Guidelines for the diagnosis and management of asthma. National Asthma Education Program/ Expert Panel Report. 1991; NIH Publication No. 913042:i-136.

17. Chai H, Farr RS, Froehlich LA, et al. Standardization of bronchial challenge procedures. J Allergy Clin Immunol 1975; 56: 323-327.

18. Crapo RO, Morris AH, Gardner RM. Reference spirometric values using techniques and equipment that meets ATS recommendations. Am Rev Respir Dis 1981; 123: 659-694.

19. Fahy JV, Steiger DJ, Liu J, Basbaum CB, Finkbeiner WE, Boushey HA. Markers of mucus secretion and DNA levels in induced sputum from asthmatic and from healthy subjects. Am Rev Respir Dis 1993; 147: 1132-1137.

20. Vathenen AS, Knox AJ, Wisniewski A, Tattersfield AK. Time course of change in bronchial reactivity with an inhaled corticosteroid in asthma. Am Rev Respir Dis 1991; 143: 1317-1321.

21. Bel EH, Timmers MC, Hermans J, Dijkman JH, Sterk PJ. The long-term effects of nedocromil sodium and beclomethasone dipropionate on bronchial responsiveness to methacholine in nonatopic asthmatic subjects. Am Rev Respir Dis 1990; 141: 21-28.

22. Gershman NH, Wong HH, Liu J, Liu H, Fahy JV. Comparison of high versus low dose fluticasone propionate (FP) on clinical outcomes and markers of inflammation in asthmatic subjects. Am J Respir Crit Care Med 1997; 155: A288. 